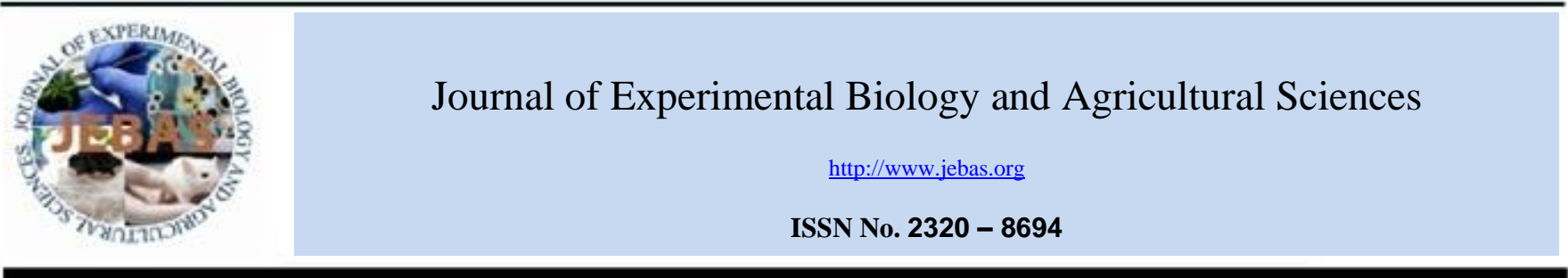

\title{
EFFECT OF HONEY CONSUMPTION AFTER PHYSICAL EXERCISES ON ELECTROLYTES AND BLOOD GLUCOSE LEVELS
}

\author{
Aliyah ${ }^{1}$, Ratna Dwi Pujiarti Rahman ${ }^{2}$, Elly Wahyudin ${ }^{3}$, Rifka Nurul Utami ${ }^{1}$, Sumarheni Sudir ${ }^{2}$ \\ ${ }^{1}$ Laboratory of Pharmaceutical Technology, Faculty of Pharmacy, Hasanuddin University, Sulawesi Selatan 90245, Indonesia \\ ${ }^{2}$ Laboratory of Clinical Pharmacy, Faculty of Pharmacy Hasanuddin University, Sulawesi Selatan 90245, Indonesia \\ ${ }^{3}$ Laboratory of Biopharmacy, Faculty of Pharmacy, Hasanuddin University, Sulawesi Selatan 90245, Indonesia \\ Received - December 30, 2020; Revision - March 28, 2021; Accepted - May 06, 2021 \\ Available Online - September 08, 2021
}

DOI: http://dx.doi.org/10.18006/2021.9(Spl-2-ICOPMES_2020).S274.S279

\section{KEYWORDS \\ Honey \\ Blood glucose \\ Electrolytes \\ Physical exercise}

\begin{abstract}
Honey has been used as food and medicine for thousands of years. The purpose of this study was to determine the effect of honey in restoring the levels of electrolytes and blood glucose after performing physical exercises. The effect of honey consumption on electrolyte and blood glucose levels was examined on 12 healthy male subjects, which were divided into 4 groups with three members in each group. Group I was treated as control and provided only $250 \mathrm{ml}$ of mineral water after exercise, while group II was provided $250 \mathrm{ml}$ commercial isotonic beverage, group III provided honey solution 1 (15 $\mathrm{ml}$ honey/250 $\mathrm{ml}$ water), and group IV provided honey solution $2(45 \mathrm{ml}$ honey/250 $\mathrm{ml}$ water). The physical exercise performed by the subjects is running on a treadmill at a speed of $5.6 \mathrm{~km} / \mathrm{h}$ for 40 minutes. Measurements of electrolyte and blood glucose levels were performed 24 hrs before as initial baseline, and these were also measured after the physical exercise as well as after the treatment. Results of the study revealed that honey played a significant role in the restore electrolyte and blood glucose levels in people who have performed physical activities such as exercising and the effect of honey is similar to the commercial isotonic beverage. However, no significant difference ( $\mathrm{p}$-value $>0.05$ ) was reported between the honey solution 1 and 2 and other treatment groups in elevating sodium and chloride level.
\end{abstract}

* Corresponding author

E-mail: aliyahputranto@yahoo.co.id (Aliyah)

Peer review under responsibility of Journal of Experimental Biology and Agricultural Sciences.

Production and Hosting by Horizon Publisher India [HPI] (http://www.horizonpublisherindia.in/).

All rights reserved.
All the articles published by Journal of Experimental Biology and Agricultural Sciences are licensed under a Creative Commons Attribution-NonCommercial 4.0 International License Based on a work at www.jebas.org.

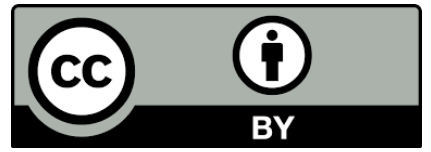




\section{Introduction}

Honey is a natural substance of a sweet thick brown, a light yellow or brown-red liquid that is produced by honey bees from the flower nectar, or secretions of plants, or excretions from plant-sucking insects (Talebi et al., 2020; Ilia et al., 2021). Honey has been used by humans for thousands of years as food and medicine, particularly it is well known for its nutritional, antimicrobial, and medicinal properties (Yusof et al., 2018; Hadju et al., 2020). Honey has a relatively complete nutrient diet and it has carbohydrates, proteins, vitamins, minerals, enzymes, polyphenols, and many other nutritive substances in sufficient concentrations. The main component of honey (ranged from $85 \%$ - 95\%) consists of carbohydrates, which materialize in the form of blood glucose and fructose and are easily absorbed by the gastrointestinal tract (Eteraf-Oskouei \& Najafi, 2013). Other components, such as proteins (amino acids and enzymes), vitamins, and minerals, are also important for the human body (Miguel et al., 2017). Honey, with its various essential components, has been widely used for teeth and gum care, insomnia, anemia, fatigue, vertigo, energy supplement, and hepatoprotective against drug toxicity (Pasupuleti et al., 2017; Aliyah et al., 2019).

About $60 \%$ of the adult human body consists of body fluids. Regulation of body fluids is particularly important and can be affected the body's salt and $\mathrm{pH}$ balance. Excessive discharge of body fluid, as happened when one is performing physical activities, sweating, vomiting, and suffering from diarrhea, can cause the decline of body fluids and electrolytes that leads to dehydration (Edwards \& Noakes, 2009). Dehydration might cause delirium, lack of concentration, and convulsions in moderate cases while it can cause coma or even death under severe conditions (Pross, 2017). When performing physical activities such as exercising, it is not uncommon for a person to lose $6-10 \%$ of his body weight due to sweating. Liquid loss due to excessive sweating can lead to dehydration if it is not replenished with the appropriate liquid (rehydration) (Popkin et al., 2010). At present, the consumption of isotonic beverages (sports drinks) to maintain body fluids and electrolytes during or after exercising has been adopted by many people in society (Larson et al., 2015). However, a previous study showed that low $\mathrm{pH} 2.4-4.5$ of isotonic drinks can cause demineralization of tooth enamel. In addition, the acidity of less than $\mathrm{pH} 5.5$ around the tooth's surface dematerializes the tooth enamel and it depends on the carbohydrate content, type, and acid concentration of the isotonic drink (Panigoro et al., 2015).

Honey could be an alternative to replace body fluids and electrolytes, apart from consuming an isotonic beverage. According to Abeshu \& Geleta (2015), honey is a reach source of minerals and nutrients and can be used as a nutritional intake for people engaging in physical activities, such as exercise. Further, honey has a higher concentration of carbohydrates (85-98\%) which are an effective replacement for blood glucose lost during exercising. Moreover, it also contains minerals, mainly sodium, potassium, and chlorine, which can be used as a substitute for lost body electrolytes (Eteraf-Oskouei \& Najafi, 2013; Abeshu \& Geleta, 2015).

Based on the aforementioned reasons, the current study aimed to determine the effect of honey consumption on electrolytes and blood glucose levels specifically following physical exercises. This is mainly based on the fact that honey can be used to replace body fluids and electrolytes, without having the disadvantages of commercially available isotonic drinks. The study was carried out on non-athlete to view whether honey can be utilized for people requiring additional nutrients after regular physical exercise.

\section{Materials and Methods}

\subsection{Materials and Devices}

The devices used in this study included treadmill (BH Fitness ${ }^{\circledR}$ ), stopwatch, digital scales (iscale ${ }^{\circledR}$ ), holder vacutainer, a tourniquet (ONEMED $®), \quad$ sphygmomanometer (OMRON® Hem-7130), glucometer (Nesco® Multicheck), electrolyte analyzer (Roche ${ }^{\circledR}$ 9180), Cobas ${ }^{\circledR C} 111$ analyzer, and laboratory glassware. All the measurement devices used were calibrated to ensure the accuracy of the experimental equipment.

The materials used in this study include aqua®, honey " $\mathrm{X}$ " (produced by the Faculty of Forestry of Hasanuddin University), isotonic beverage "Y" obtained from supermarkets, reagent for Cobas ${ }^{\circledR}$ GLUC2, alcohol swab (ONEMED®), round plaster (PLESTERIN $®$ Round), vacutainer needle $(\mathrm{BD} \circledast$ Vacutainer), plain vacutainer tube of $3 \mathrm{cc}\left(\mathrm{ONEMED}{ }^{\circledR}\right.$ Vaculab).

\subsection{Study Sample}

A total of 12 healthy adult male subjects, aged between 18-30 years with body mass index between 18.5 - 27.0 were randomly selected. Subjects included in this study are physically fit and met the following criteria: Willing to be involved in the current study (and therefore should be willing to fill out the informed consent letter), do not have any allergies to honey or isotonic beverages, willing to consume honey or isotonic beverages, not a professional athlete, having normotension or blood pressure at/or approximately $110 / 70 \mathrm{~mm} \mathrm{Hg}$. Subjects were not included in this study if they were on an extreme dietary restriction, consuming honey daily, taking drugs that can change fluid and electrolyte balance, having an acute or chronic disease that can affect the results of the study (e.g., renal dysfunction), having abnormal levels of serum electrolyte and blood glucose. 


\subsection{Honey Solution}

The type of honey used in this study was Trigona honey produced by Trigona species. The honey solution was made into two concentrations using 1 and 3 tablespoons of honey, respectively (6\% $\mathrm{v} / \mathrm{v}$ and $18 \% \mathrm{v} / \mathrm{v})$. The honey solution $1(\mathrm{HS} 1)$ was prepared by dissolving $15 \mathrm{ml}$ of honey with aqua ${ }^{\circledR}$ in an Erlenmeyer flask of 250 $\mathrm{ml}$ volume and stirred homogeneously while the honey solution 2 (HS2) was prepared in the same way using $45 \mathrm{ml}$ of honey.

\subsection{Examining the Effect of Honey Consumption on Electrolyte and Blood Glucose Levels}

For estimation of blood glucose level and electrolytes after honey consumption was determined by the Armstrong et al.(2012) method with some modification. This method was approved by the Commission of Ethics for Health Research, Faculty of Medicine, Hasanuddin University (883/H4.8.4.5.31/ P36-KOMETIK/2017). Briefly, before conducting the study, subjects were directed to not eat for at least $8 \mathrm{hrs}$ and not drink for at least an hour before the study began. The respondents were divided into 4 groups, and each group consisted of 3 respondents, details of divided groups was as Group I was considered as control and given $250 \mathrm{ml}$ of aqua ${ }^{\circledR}$ (G1), while Group II was given $250 \mathrm{ml}$ of commercial isotonic drink (G2), Group III was given $250 \mathrm{ml}$ of HS1 (G3), Group IV was given $250 \mathrm{ml}$ of HS2 (G4).

Before exercising, the blood pressure of each respondent was measured by professional healthcare while the body mass indexes (BMI) of the respondents were calculated by using the following formula (Table 1).

$$
\frac{\text { wieght }(\mathrm{kg})}{\text { height }(\mathrm{m})^{2}}
$$

Initial blood glucose and electrolyte $\left(\mathrm{Na}^{+}, \mathrm{K}^{+}, \mathrm{CI}\right)$ levels of the selected respondents were measured one day before the day of exercise (H-24) by taking a blood sample from the venous by using $\mathrm{BD}{ }^{\circledR}$ vacutainer system of blood collection. All the selected respondents were asked to run for 40 minutes on a treadmill (5.6 $\mathrm{km} /$ hour). After the exercise ends, they were allowed to rest for 5 minutes, and this was followed by the weighed and measured their blood glucose and electrolytes $\left(\mathrm{Na}^{+}, \mathrm{K}^{+}, \mathrm{CI}\right)$ levels as the baseline (H0). Later on, each group was provided an appropriate drink according to the predicted group treatment. After 60 minutes without any heavy physical activity, the respondents from each group were reweighed, and $3 \mathrm{ml}$ of venous blood sample was taken for the estimation of blood glucose and electrolyte $\left(\mathrm{Na}^{+}, \mathrm{K}^{+}, \mathrm{CI}\right)$ level $(\mathrm{H}+1)$. The same procedure was also carried out after 2 hours of exercise $(\mathrm{H}+2)$. The collected blood samples were centrifuged for 15 minutes at $3000 \mathrm{rpm}$ to obtain serum. The electrolyte levels were measured by Roche ${ }^{\circledR} 9180$ electrolyte analyzer, and the blood glucose level was measured by using the Cobas ${ }^{\circledR} \mathrm{C} 111$ analyzer.

\subsection{Data Collection and Analysis}

The variables analyzed in this study were electrolytes and blood glucose levels with different treatment groups at different periods, before and after the physical exercise. The obtained data were analyzed using the statistical program SPSS Ver. 16. To assess the effect of the treatment, one-way ANOVA (Analysis of Variance) and Post-Hoctest were performed to see its differences.

\section{Results and Discussion}

The effects of honey consumption on electrolyte and blood glucose levels of the respondents who perform physical exercise was studied before and after running and 1 and 2 hours after taking the assigned drink.

All the selected respondents have met the age criteria of 18-30 years with an average of $22 \pm 0.1$ years old. Data given in table 1 suggested that all respondents had blood pressure that met the inclusion criteria of being normotension or an average $110 / 70 \pm 12.64 / 7.61 \mathrm{mmHg}$. The body mass index (BMI) data also shows that all respondents involved in this study, could not be categorized as obese $(\mathrm{BMI}>30)$ or underweight $(\mathrm{BMI}<17)$.

Table 1 Body Mass Index (BMI), and blood pressure of volunteers prior to exercise testing

\begin{tabular}{|cccc|}
\hline $\begin{array}{c}\text { Subject } \\
\text { code }\end{array}$ & Age (years) & $\begin{array}{c}\text { Blood pressure } \\
(\mathrm{mmHg})\end{array}$ & Body Mass Index \\
\hline 1 & 21 & $105 / 68$ & 27.0 \\
\hline 2 & 22 & $107 / 69$ & 18.5 \\
\hline 3 & 20 & $128 / 69$ & 26.9 \\
\hline 4 & 21 & $105 / 75$ & 20.9 \\
\hline 5 & 22 & $106 / 73$ & 18.0 \\
\hline 6 & 22 & $126 / 68$ & 24.4 \\
\hline 7 & 23 & $110 / 70$ & 21.2 \\
\hline 8 & 24 & $112 / 78$ & 19.7 \\
\hline 9 & 22 & $121 / 86$ & 21.7 \\
\hline 10 & 21 & $106 / 69$ & 18.8 \\
\hline 11 & 22 & $107 / 68$ & 22.1 \\
\hline 12 & 22 & $127 / 81$ & 20.7 \\
\hline
\end{tabular}

Initial vein blood withdrawal from the respondents was used as the basal value to minimize the effects of the diet on electrolyte and blood glucose levels in the respondents who would perform the exercise. The results of the initial electrolyte and blood glucose level measurement of the respondents are presented in table 2 . The average initial electrolyte and blood glucose levels of the respondents are within the range of reference values $\left(\mathrm{Na}^{+} 136-145\right.$ $\mathrm{mmol} / \mathrm{L} ; \mathrm{K}^{+} 3.5-4.5 \mathrm{mmol} / \mathrm{L} ; \mathrm{Cl}^{-} 98-107 \mathrm{mmol} / \mathrm{L}$; Blood glucose $80-120 \mathrm{mg} / \mathrm{dL}$ ). 
Tabel 2 Initial serum level of electrolytes and glucose in volunteers before exercise

\begin{tabular}{|cccccc|}
\hline No & Group of treatment & $\begin{array}{c}\text { Sodium } \\
(\mathrm{mmol} / \mathrm{L})\end{array}$ & Potassium $(\mathrm{mmol} / \mathrm{L})$ & $\begin{array}{c}\text { Chloride } \\
(\mathrm{mmol} / \mathrm{L})\end{array}$ & $\begin{array}{c}\text { Glucose } \\
(\mathrm{mg} / \mathrm{dL})\end{array}$ \\
\hline 1. & $\mathrm{G} 1$ & $136.3 \pm 3.8$ & $4.1 \pm 0.7$ & $102.7 \pm 2.1$ & $107.0 \pm 2.6$ \\
\hline 2. & $\mathrm{G} 2$ & $141.0 \pm 1.7$ & $4.3 \pm 0.6$ & $105.0 \pm 3.5$ & $93.0 \pm 28.4$ \\
\hline 3. & $\mathrm{G} 3$ & $137.3 \pm 2.1$ & $4.1 \pm 0.2$ & $103.3 \pm 2.9$ & $100.7 \pm 4.0$ \\
\hline 4. & $\mathrm{G} 4$ & $136.0 \pm 2.0$ & $4.1 \pm 0.2$ & $103.3 \pm 2.3$ & $103.3 \pm 14.6$ \\
\hline
\end{tabular}

Values are mean $\pm \mathrm{SD}$, G1 was given $250 \mathrm{ml}$ of aqua ${ }^{\circledR}, \mathrm{G} 2$ was given $250 \mathrm{ml}$ of commercial isotonic drink, G3 was given $250 \mathrm{ml}$ of $\mathrm{HS} 1$, G4 was given $250 \mathrm{ml}$ of $\mathrm{HS} 2$. Reference values in blood healthy adult man of $\mathrm{Na}^{+} 136-145 \mathrm{mmol} / \mathrm{L} ; \mathrm{K}^{+} 3.5-4.5 \mathrm{mmol} / \mathrm{L} ; \mathrm{Cl}^{-} 98-107$ $\mathrm{mmol} / \mathrm{L}$; Glucose $80-120 \mathrm{mg} / \mathrm{dL}$.
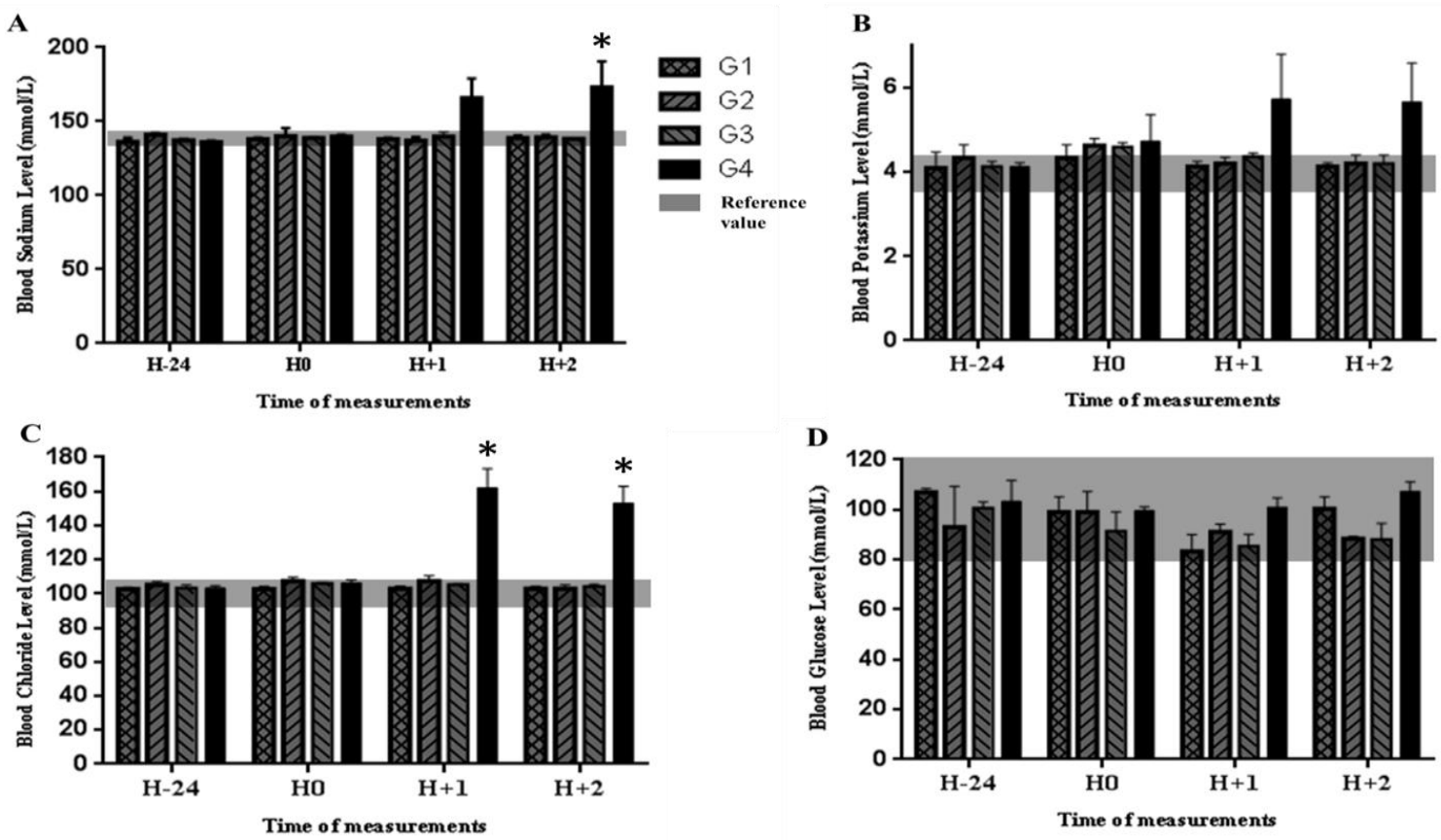

Figure 1 Blood electrolyte and glucose levels in the selected respondents, measured at 24hrs before physical exercise (H-24), before treatment $(\mathrm{H} 0)$, an hour after treatment $(\mathrm{H}+1)$, and $2 \mathrm{hrs}$ after treatment $(\mathrm{H}+2)$; Values are mean $\pm \mathrm{SD}$, all the used treatment abbreviations are similar to table $2(* \mathrm{p}<0.05$ : significant difference compared to other treatments by one-way ANOVA)

Results presented in figure 1 revealed that one hour after the treatment of water (G1), isotonic beverage $(\mathrm{G} 2)$, or the honey solution 1 (G3), the levels of electrolyte and blood glucose were relatively stable and are in the range of reference value. Based on the results of statistical data analysis of electrolyte levels, there was no significant difference was reported between the treatment groups ( $p$ > 0.05). While in the case of $\mathrm{G} 4$, a rapid increase was reported in the level of the electrolyte after one hour of the treatment by honey solution 2 and this elevation remained high even after 2 hours of treatment. This increased in electrolyte levels might be due to the intake of isotonic beverage or honey because both solutions having electrolyte ions which can be used to replace lost electrolytes during exercising. Further, $250 \mathrm{ml}$ of the commercial isotonic beverage has $5.25 \mathrm{mmol}$ of sodium, 1.25 mmol of potassium, and $4 \mathrm{mmol}$ of chloride while in the case of
$100 \mathrm{ml}$ of honey contains $0.03-1.74 \mathrm{mmol}$ of sodium, $0.26-12.05$ mmol of potassium, and $0.06-0.6 \mathrm{mmol}$ of chloride (Ajibola et al., 2012). However, after the electrolyte level increases, the body's homeostatic system will balance the intracellular and extracellular level of electrolytes to the normal reference values $\left(\mathrm{Na}^{+} 136-145\right.$ $\left.\mathrm{mmol} / \mathrm{L} ; \mathrm{K}^{+} 3.5-4.5 \mathrm{mmol} / \mathrm{L} ; \mathrm{Cl}^{-} 98-107 \mathrm{mmol} / \mathrm{L}\right)$.

This effect showed relatively slower on the G4 group which still has a high level of electrolytes even after 2 hours of consuming the solution containing 3 tablespoons of honey. Similarly, Saat et al. (2002) reported that the electrolyte levels (sodium, potassium, and chloride) increased after physical activity including exercises. After drinking, the electrolyte levels in the respondent's blood decreased over time to resume the initial electrolyte levels in all treatment groups (Saat et al., 2002). 
During running, the body experiences hypertonic and hypovolemic states due to sweating. Previous studies revealed that the released sweat contains $20-80 \mathrm{mmol} / \mathrm{L}$ of sodium, $4-8 \mathrm{mmol} / \mathrm{L}$ of potassium, and $20-60 \mathrm{mmol} / \mathrm{L}$ of chloride. To maintain the osmolarity of the body, intracellular fluid shifts to the extracellular space. Plasma volume will decrease, and plasma osmotic pressure rises to maintain the lack of fluid in the body (Sawka et al., 2015). Osmotic pressure increased along with the increased levels of sodium and chloride in the plasma and declining water concentrations (Kenefick et al., 2012; Singh, 2003). Intracellular to the extracellular space transfer of potassium also occurs because the extracellular potassium is released along with sweat as the result of increased body heat. Therefore, to maintain extracellular potassium levels, intracellular potassium shifts to extracellular space (Gröber, 2009).

The average blood glucose level of the respondents seemingly decreased after running as shown in figure 1D. A decrease in blood glucose levels after physical exercise occurs since the body needs energy in the form of ATP. The largest source of energy is obtained from carbohydrates which are broken down into glucose and converted these glucose molecules in ATP through glycolysis, oxidative decarboxylation, Krebs cycle, and electron transfer (Rodwell et al., 2018). Although the blood glucose level of all respondents of G1, G2, and G3 groups remained lower than the initial level two hrs after isotonic beverage or honey solutions intake, the levels were still within reference value of 80-120 $\mathrm{mg} / \mathrm{dL}$. In contrast with this, in the G4 group, the subjects experienced a rapid increase in glucose levels one hr after the honey solution 2 consumption. However, based on the results of statistical analysis of glucose levels $(\mathrm{p}<0.05)$, the Post-Hoc test analysis showed that there was no significant difference between the treatment groups of honey solution 1 and honey solution 2 with other treatment groups.

Electrolytes and glucose play an important role in the body such as the formation of energy and action potentials processes. Overactive people can lose fluids and electrolytes excessively. Lack of fluids and excessive electrolytes can cause dehydration which can lead to delirium, seizures, and even death in certain cases (Sherwood, 2012). It is important to replace lost fluids and electrolytes in the body so that the cells can carry out their functions properly. Rehydration to replenish lost body fluids and electrolytes is necessary to keep our body cells nourished. Still, this study has some limitations, including small sample size and a short study duration. This emphasizes the requirement for further study with a larger sample size and longer duration.

\section{Conclusion}

From the results of this study, it can be concluded that mixing 250 $\mathrm{ml}$ honey in water can restore electrolyte and blood glucose levels in people who have performed physical activities including exercise. However, there is no significant difference between other treatments, except for sodium and chloride level elevation within the administration of $18 \% \mathrm{v} / \mathrm{v}$ honey solution. Nevertheless, it is important to note that these findings show that honey possesses the ability to restore electrolyte and glucose levels without necessarily having the side effect of commercial isotonic drinks.

\section{Acknowledgment}

We would like to thank Mrs. Ruly S.ST, M.Kes from Dadi Hospital, and Dean of Faculty of Pharmacy, Hasanuddin University, Prof. Subehan for their help and contribution to this research.

\section{Conflict of interest}

The authors declare no conflict of interest in this study.

\section{References}

Abeshu MA, Geleta B (2015) Medicinal Uses of Honey. Biology and Medicine 8: 1-7.

Ajibola A, Chamunorwa JP, Erlwanger KH (2012) Nutraceutical values of natural honey and its contribution to human health and wealth. Nutrition \& Metabolism 9: 61-61.

Aliyah A, Wahyudin E, Kaelan C (2019) Hepatoregenerative effects of honey essence of paliasa on the liver of rat induced with carbon tetrachloride. Drug Invention Today 12(4): 646-651.

Armstrong LE, Johnson EC, Munoz CX, Swokla B, Le Bellego L, Jimenez L, Casa DJ, Maresh CM (2012) Hydration biomarkers and dietary fluid consumption of women. Journal of the Academy of Nutrition and Dietetics 112(7):1056-61. doi: 10.1016/ j.jand.2012.03.036.

Edwards AM, Noakes TD (2009) Dehydration. Sports Medicine 39(1): 1-13

Eteraf-Oskouei T, Najafi M (2013) Traditional and modern uses of natural honey in human diseases: a review'. Iranian Journal of Basic Medical Sciences 16(6): 731-42.

Gröber U (2009) Micronutrients: Metabolic Tuning - Prevention Therapy. Drug Metabolism and Drug Interactions 24(2-4): 331331.

Hadju V, Dassir M, Sadapotto A, Putranto A, Marks G, Arundhana AI (2020) Effects of Moringa Oleifera Leaves and Honey Supplementation during Pregnancy on Mothers and Newborns: A Review of the Current Evidence. Open Access Macedonian Journal of Medical Sciences 8(F): 208-214. 
Ilia G, Simulescu V, Merghes P, Varan N (2021) The health benefits of honey as an energy source with antioxidant, antibacterial and antiseptic effects. Science \& Sports 36(4): 272.e1-272.e10.

Kenefick RW, Cheuvront SN, Montain SJ, Carter Iii R, Sawka MN (2012) Human Water and Electrolyte Balance. Present Knowledge in Nutrition, Pp. 493-505.

Larson N, Laska MN, Story M, Neumark-Sztainer D (2015) Sports and energy drink consumption are linked to health-risk behaviours among young adults. Public Health Nutrition 18(15): 2794-803.

Miguel MG, Antunes MD, Faleiro ML (2017) Honey as a Complementary Medicine. Integrative Medicine Insights 12: 1178633717702869. doi: 10.1177/1178633717702869.

Panigoro S, Pangemanan DHC, Juliatri J (2015) Kadar Kalsium Gigi yang Terlarut pada Perendaman Minuman Isotonik. e-GiGi 3(2): 356-360.

Pasupuleti VR, Sammugam L, Ramesh N, Gan SH (2017) Honey, Propolis, and Royal Jelly: A Comprehensive Review of Their Biological Actions and Health Benefits. Oxidative Medicine and Cellular Longevity 2017: 1259510. https://doi.org/10.1155/2017/ 1259510 .

Popkin BM, D'Anci KE, Rosenberg IH (2010) Water, hydration, and health. Nutrition Reviews 68(8): 439-58.
Pross N (2017) Effects of Dehydration on Brain Functioning: A Life-Span Perspective. Annals of Nutrition and Metabolism 70(suppl 1): 30-36.

Rodwell VW, Bender DA, Botham KM, Kennelly PJ, Weil PA (2018) Harper's Illustrated Biochemistry, Thirty-first Edition. New York: Lange Medical Books/McGraw Hill.

Saat M, Singh R, Sirisinghe RG, Nawawi M (2002) Rehydration after exercise with fresh young coconut water, carbohydrateelectrolyte beverage and plain water. Journal of Physiological Anthropology 21:93-104.

Sawka MN, Cheuvront SN, Kenefick RW (2015) Hypohydration and Human Performance: Impact of Environment and Physiological Mechanisms. Sports medicine (Auckland, N.Z.) 45 (Suppl 1): S51-S60.

Sherwood L (2012) Fundamentals of Human Physiology. Belmont, California: Cole, Cengage Learning.

Singh R Jr. (2003) Fluid balance and exercise performance. Malaysian Journal of Nutrition 9(1): 53-74.

Talebi M, Talebi M, Farkhondeh T, Samarghandian S (2020) Molecular mechanism-based therapeutic properties of honey. Biomedicine \& Pharmacotherapy 130: 110590.

Yusof A, Ahmad NS, Hamid MSA, Khong TK (2018) Effects of honey on exercise performance and health components: A systematic review. Science \& Sports 33(5): 267-281. 